\title{
Sonic Boom Mitigation by Shaping the Nose of Supersonic Biplane
}

\author{
大久保 正幸*2 豊 田篤*2 山 下 博*2 \\ Masayuki Okubo, Atsushi Toyoda, Hiroshi Yamashita, Toshihiro Ogawa, Shigeru Obayashi,

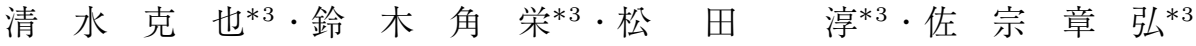 \\ Katsuya Shimizu, Kakuei Suzuki, Atsushi Matsuda and Akihiro Sasoh
}

Key Words : Supersonic Biplane-Airfoil, Wing-Body Configuration, Sonic Boom, CFD, Ballistic Range Experiment

\begin{abstract}
To examine the possibility of sonic boom mitigation by the supersonic biplane with a fuselage, two kinds of wing-fuselage models for the ballistic range experiment were designed by using CFD simulations. One was the low-boom model with a blunt nose and the other was the high-boom model with a spike nose. From the CFD result, the near-field pressure strength from the low-boom model becomes $70 \%$ of that of the high-boom model. The far-field pressure peak of the low-boom model becomes $85 \%$ of that of the high-boom model. To verify the near-field pressure signature calculated by CFD, the experimental model using the supersonic biplane with a finite-thickness leading edge was designed and launched with the ballistic range. As a result, the reliability of the CFD result was confirmed.
\end{abstract}

\section{1. 序論}

人々がより速く快適に世界各地の目的地へ到達できるこ とは大きなメリットであり, 高速化は航空市場に扔ける残 されたニッチの 1 つといえる. 現在，超音速旅客機は運行 されておらず，次世代超音速旅客機が実現すれば，大きな 市場を開拓できる可能性がある。一方，超音速旅客機実現 には未だ克服すべき技術的な課題が存在する。

航空機が超音速で飛行する際, 機体各部から衝撃波が発 生し，地上で非常に大きな爆発音をもたらすことが知られ ている，これをソニックブームと呼び, 技術課題の 1 つと なっている，また，機体各部から発生する衝撃波によって 造波抵抗が大きくなるため, 超音速機は亜音速機に比べて 燃費効率が著しく悪化する。これらの問題が, 超音速旅客 機が現在運航されていない主要な原因である。筆者らの研 究グループは, この問題を解決する方法として航空機の翼 に複葉を採用し，翼間で衝撃波と澎張波を干涉・相殺させ ることで, ソニックブーム騒音と造波抵抗の大幅な低減化 を検討している1 4). 過去に行われた風洞実験や数值計算結 果から, 複葉翼単体での低ブーム効果は示されている5 ${ }^{5,6)}$. しかし, 翼胴形態7)での低ブーム性能に関する研究例は少 ない.

翼胴形態の低ブーム化に関する研究例としては, 2003

\footnotetext{
*1 C 2011 日本航空宇宙学会

平成 22 年 3 月 10 日, 日本航空宇宙学会北部支部 2010 年講演 会に打いて発表. 平成 22 年 5 月 27 日原稿受付

*2 東北大学流体科学研究所

*3 名古屋大学大学院工学研究科
}

年に F-5E (単葉翼機) の機首形状に修正を施した SSBD

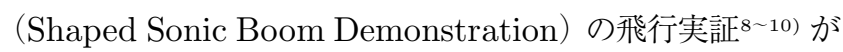
行われ，ソニックブームの圧力上昇を大幅に低減できるこ とが実証された。この低減方法を超音速複葉翼機に応用す れば，全機から発生するソニックブーム強度の低減化が期 待できる。一方, 超音速複葉翼の衝撃波干渉・相殺効果によ る低ブーム性を活かすには, 胴体の影響が少ない全翼機も 候補にあがる。しかし，全翼機は将来的に実現可能だと考 えられるが, 現時点では, 静安定性や与圧時の強度確保な どで技術的課題が多く, 従来航空機に似た翼胴形態の方が, より実現性が高いと考えられる。こうした背景から，超音 速複葉翼を用いた翼胴形態での低ブーム効果の検証につい て検討する。

本稿では, 胴体先端形状修正による翼胴型超音速複葉翼 機のソニックブーム低減化を検討した。具体的には, CFD (Computational Fluid Dynamics) を用いて胴体先端形状 を変更した場合のソニックブーム波形の変化掠よび同体と 翼胴干渉に着目し, 翼胴型超音速複葉翼の実験模型の設計 を行った。次に，設計した模型に対してバリスティックレ ンジ11 13) を用いた超音速自由飛行実験を行い，CFD 解析 結果の妥当性を検証した，得られた結果から胴体先端形状 修正による翼胴型超音速複葉翼機のブーム低隇化の可能性 を示す。

\section{2. 翼胴型実験模型}

実験模型は翼胴型複葉翼機の基本形状をもとに, ランダ ムサーチ法とソニックブーム先端衝撃波強度の簡易推算法 である First cut 法 ${ }^{14)}$ を用いて, 模型の胴体先端形状を設 


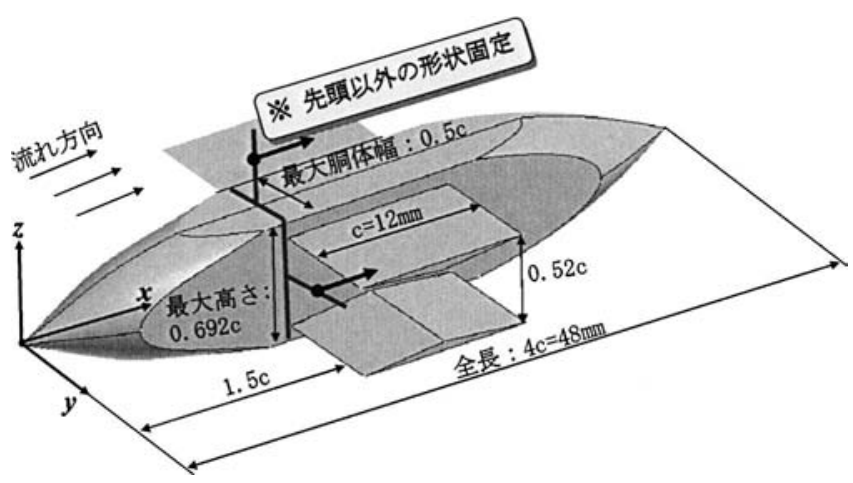

第 1 図＼cjkstart翼胴型複葉翼実験模型の基本形状

計した。 その際, 複葉翼の影響を無視し, 翼体積をゼロと した。 以下に設計手順を述べる。

2.1 基本形状 第 1 図に実験模型の基本形状を示す。胴 体側面は平面とし, 胴体から発生する衝撃波や膨張波が複 葉翼の翼間干渉へ与える影響を小さくするよう設計した。 胴体と複葉翼の接続位置については, 胴体先端から発生す るマッハコーン内に複葉翼が収まるように配置し, 翼間距 離は翼前縁から発生した斜め衝撃波の屈折および境界層厚 さを考慮して設定した。また，胴体先端部は低ブーム化の ため変化可能であり, それ以外の全長, 最大胴体幅, 最大 高さ，複葉翼の寸法はすべて固定した。

2.2 先端衝撃波強度の簡易推算法 ソニックブームを 計算する手法として波形パラメータ法 ${ }^{15)}$ が広く用いられて いるが，この手法ではオイラー方程式を解き，近傍場圧力 分布を求める必要があるため, 計算コストが高くなる。 そ こで, より簡便にソニックブームの先端衝撃波強度を推算 可能な First cut 法を用いた. 先端衝撃波強度 $\Delta P$ の推算 式を式 (1) に示す.

$$
\Delta P=P_{\mathrm{g}} \cdot k_{\mathrm{r}} \cdot k_{\mathrm{a}} \cdot \beta^{1 / 4} \cdot(h / L)^{-3 / 4} \cdot K_{\mathrm{s}}
$$

ここで $h$ は飛行高度， $L$ は機体長， $k_{\mathrm{r}}$ は反射率， $k_{\mathrm{a}}$ は減衰 係数で $k_{\mathrm{a}}=K_{\mathrm{A}} \cdot \operatorname{sqrt}\left(P_{\mathrm{h}} / P_{\mathrm{g}}\right)$ で定義される。ここで $K_{\mathrm{A}}$ は大気増幅係数, $P_{\mathrm{g}}$ は地上大気圧, $P_{\mathrm{h}}$ は飛行高度での大気 圧である。また $\beta$ は $\operatorname{sqrt}\left(M^{2}-1\right)$ で定義され， $M$ はマッ 八数である. $K_{\mathrm{s}}$ は形状係数で式 $(2)$ で表される.

$$
K_{\mathrm{s}}=\sqrt{\int_{0}^{x_{0}} F(x) \mathrm{d} x}
$$

$K_{\mathrm{S}}$ は機体形状に依存する変数である， $x$ は機体の先端を原 点として機軸方向に測った距離であり，積分の上限 $x_{0}$ は $F(x)=0$ の根のうち, 本積分に正の最大值を与える根で ある. 式中の $F(x)$ は $F$ 関数と呼ばれ式 $(3)$ で表される.

$$
F(x)=\frac{1}{2 \pi} \int_{0}^{x} \frac{S^{\prime \prime}(\eta)}{\sqrt{x-\eta}} \mathrm{d} \eta
$$

$S(\eta)$ はマッハ面による機体の切断面を機体軸方向に投影し た相当回転体の断面積で, $S^{\prime \prime}(\eta)$ はその 2 階微分である.

2.3 胴体先端形状の決定 簡易推算手法を用いて胴体 先端形状を決定した。第 2 図は胴体先端部形状の決定手順

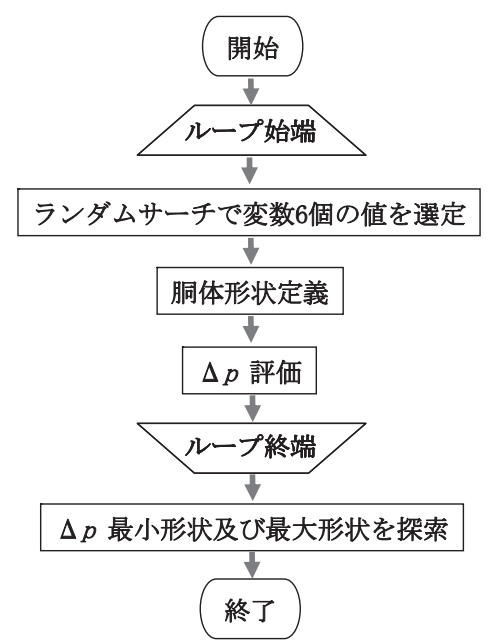

第 2 図＼cjkstart胴体先端形状の決定手順

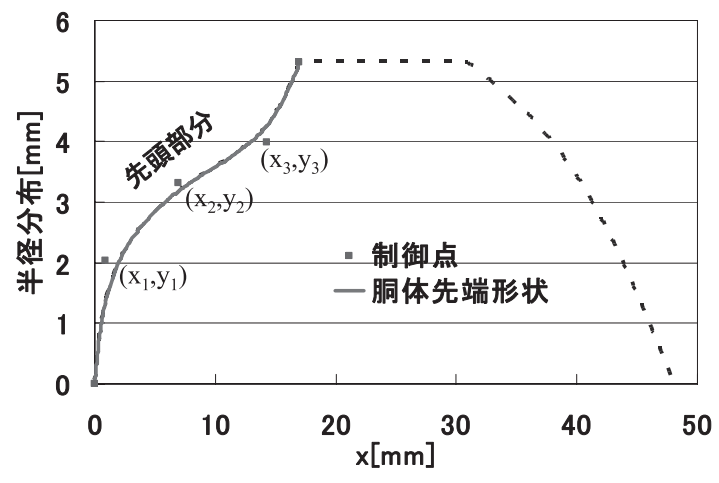

第 3 図 胴体形状の半径分布と先端形状部の設計変数

を示す，胴体先端部をあらわす半径分布は，第 3 図のよう に 3 つの制御点を持つ B スプライン曲線で表現する。設計 変数は, この制御点の機軸方向座標および垂直座標であり 合計 6 つである. 設計変数の定義域を次式 (4)で定義した.

$$
\begin{aligned}
& 0.5 \leq x_{1} \leq 5.0 \quad[\mathrm{~mm}] \\
& 5.5 \leq x_{2} \leq 10.0 \\
& 10.5 \leq x_{3} \leq 15.0 \\
& 1.0 \leq y_{1} \leq 2.5 \\
& 2.5 \leq y_{2} \leq 3.5 \\
& 3.5 \leq y_{3} \leq 5.0
\end{aligned}
$$

次に，ランダムサーチ法を用いてこれら 6 つの設計変数 值を選定した後, 得られた変数值に対して B スプライン曲 線（第 3 図中の実線）で胴体先端形状を表現する。胴体後方 部形状 (第 3 図中の点線) は固定して胴体形状の半径分布を 定義する。ささらにFirst cut 法（式 (1)）を用いて先端衝撃 波強度 $\Delta P$ を評価する。 その際, $h / L$ を求める必要がある が本論文では飛行高度 $60,000 \mathrm{ft}$, 機体長 $202 \mathrm{ft}$ (Concorde 機体長）を参考值として用い， $h / L$ を求めた。なお，マッ 八数 1.7 とした。 この手順を 5,000 回繰り返し, 先端衝撃 波強度 $\Delta P$ の最小形状と, 比較対象として $\Delta P$ の最大形状 を求めた。第 4 図は得られた模型形状を比較して示す。 


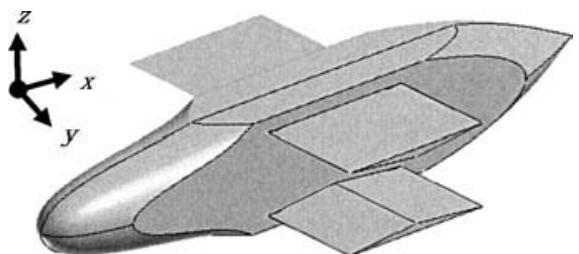

(a) ブーム最小形状

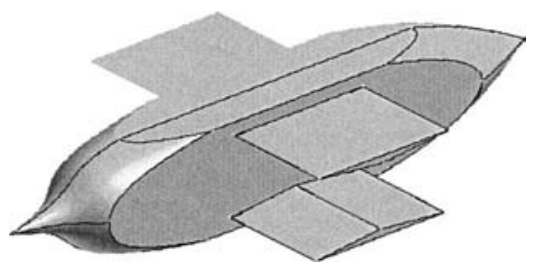

(b) ブーム最大形状

第 4 図 ランダムサーチで得られた実験模型形状

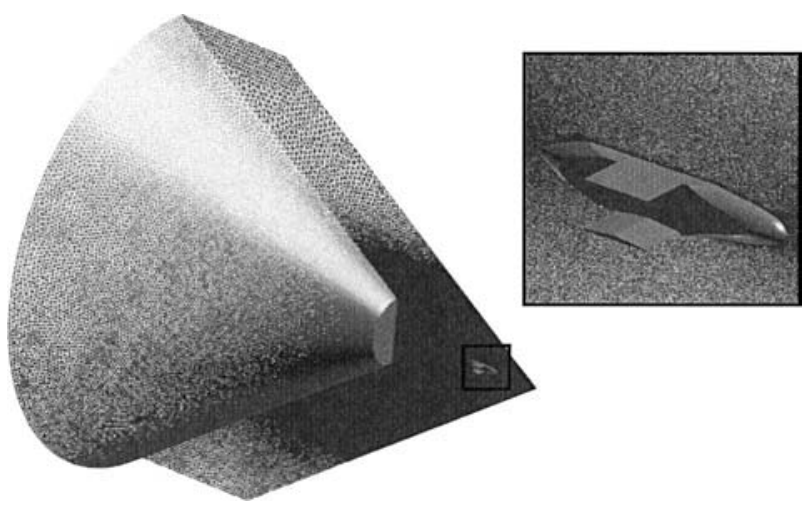

第 5 図 CFD 解析に用いた計算格子

\section{3. 数值解析手法}

CFD 解析を用いて，第 4 図に示す 2 つの実験模型形状の 低ブーム効果を検討した. CFD 解析は 3 次元非構造格子流 体ソルバーである TAS code (Tohoku University Aerodynamic Simulation code) ${ }^{16)}$ を用いて Euler 計算を行った. 計算格子は, 非構造格子生成ツールである Edge Editor ${ }^{17)}$ およびTU TETRAGRID ${ }^{18)}$ を用いて作製した。翼間での 衝撃波干涉および胴体から発生する衝撃波を精度よく捕ら えられるように機体長 4 倍位置まで格子を細かくとった。 格子点数は約 1,200 万点である。第 5 図に計算格子を示す. 模型から発生するソニックブームは波形パラメータ法15) を用いて推算した。波形パラメー夕法の入力である近傍場 圧力波形は 2 機体長直下の圧力分布を用い, 飛行条件は飛 行マッハ数 1.7 , 飛行高度 $60,000 \mathrm{ft}$, 機体長 $202 \mathrm{ft}$ の巡航 状態として計算を行った。大気条件には標準大気を用いた。

\section{4. 胴体先端部形状の違いがブーム波形へ及ぼす影響}

第 6 図には，第 4 図に示す 2 つの実験模型形状について 近傍場圧力波形（2 機体長下）を比較して示す。また第 7 図にソニックブームの比較結果を示す。なお, 第 7 図には 各々の模型について胴体のみの結果も合わせて示す.

第 6 図より,ブーム最小形状はブーム最大形状に比べて,

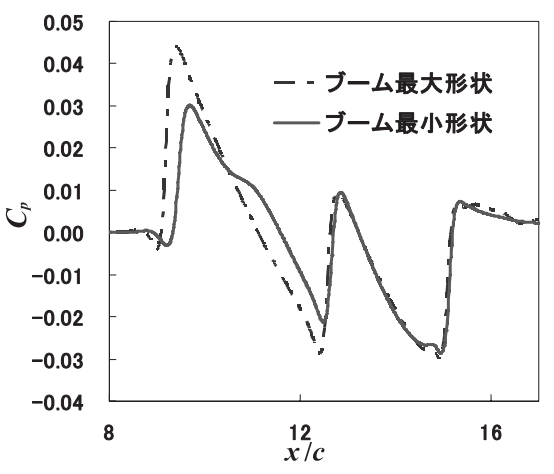

第 6 図 近傍場圧力分布の比較

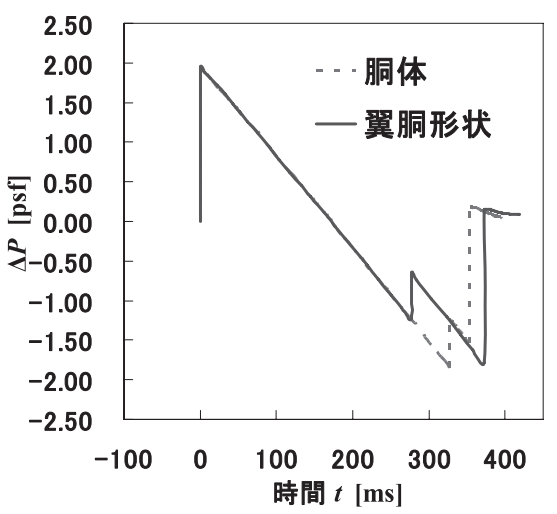

(a) ブーム最小形状

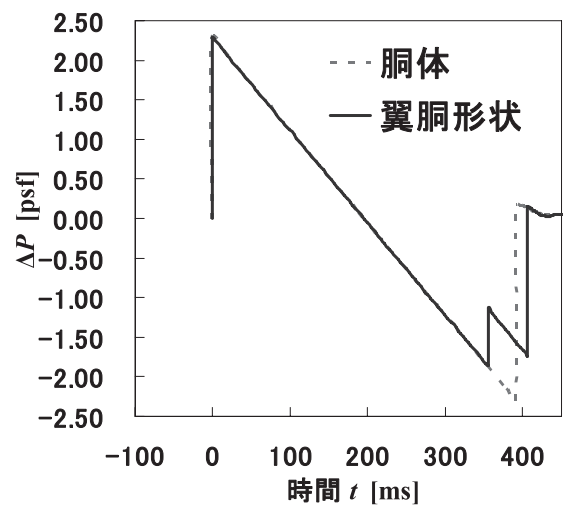

(b) ブーム最大形状

第7図 ソニックブーム波形の比較

近傍場でピーク圧值が減少していることがわかる．また，第 7 図から,ブーム最小形状およびブーム最大形状の両者と も, 翼胴形状と胴体のみの先端圧力ピーク值は等しい. こ のことからブーム強度には胴体の影響が大きく, 複葉翼の 影響が小さいことがわかる。 さらに，両模型形状について 先端圧力ピーク值を比較すると, ブーム最小形状は $1.94 \mathrm{psf}$ であるのに対して, ブーム最大形状は $2.29 \mathrm{psf}$ となり, 最小 形状はブーム強度を約 $15 \%$ 低減していることが確認できる.

\section{5. 翼前縁および後縁に厚みを持たせた実験模型形状}

実験模型は翼弦長が $12 \mathrm{~mm}$ と短く，模型製作上，複葉翼 の前縁および後縁に厚みを持たせる必要がある。本実験模 
型では加工費の面から翼前縁および後縁に $0.2 \mathrm{~mm}$ の厚み を持たせた，一方，翼前縁に厚みを持たせることで離脱衝 撃波が発生し斜め衝撃波角が変化する。従って可能な限り 翼間での理想的な衝撃波干渉を達成するため, 製作模型で は翼間距離を大きくとった。第 8 図は翼前縁および後縁に 厚みをつけた複葉翼を用いたブーム最小形状およびブーム 最大形状を示す。また両模型について, 第 9 図にCFD 解 析で得られた近傍場圧力波形（2 機体長下）を示し，第 10 図に 3 節で示した飛行条件で, 波形パラメー夕法を用いて 推算した地上ソニックブーム波形を比較して示す.

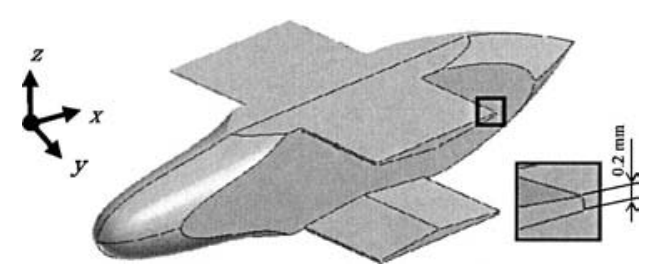

(a) ブーム最小形状

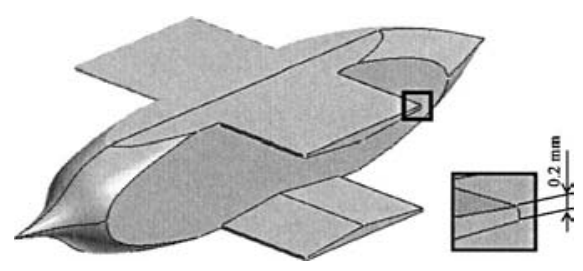

(b) ブーム最大形状

第 8 図 翼前縁と後縁に厚みをつけて製作した実験模型形状

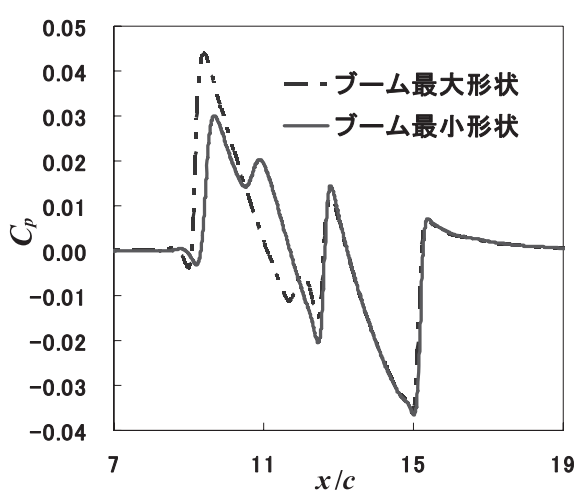

第 9 図 製作模型の近傍場圧力分布 (2 機体長下) の比較

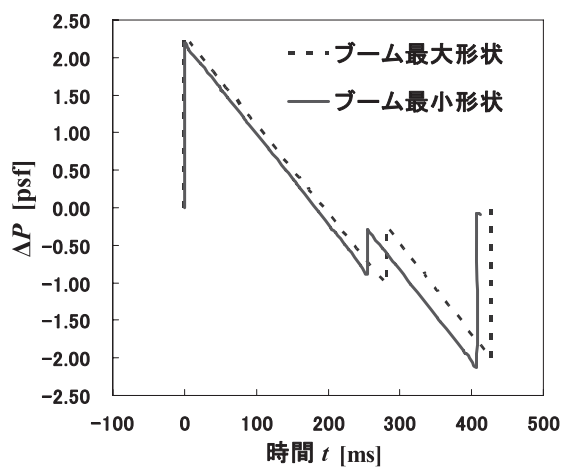

第 10 図 製作模型のソニックブーム波形の比較
第 9 図より翼の前縁に厚みがある形状でも，ブーム最小 形状はブーム最大形状に比べて, 近傍場圧力ピーク值が大 幅に低減されている，しかし，第10図で示す地上ブーム波

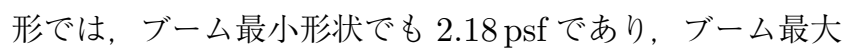
形状の $2.29 \mathrm{psf}$ に比べ約 $5 \%$ の低減にとどまった.

\section{6. 翼前縁から発生する衝撃波が ブーム波形へ及ぼす影響}

模型製作の都合で翼前縁に厚みを持たせたところブーム 最小形状のブーム低減効果が小さくなった。この原因を議 論するため, 飛行条件をマッ八数 1.7 および機体長 $202 \mathrm{ft}$ で固定し, 波形パラメー夕法によって各飛行高度に扔ける 地上ブーム波形を推算した。第 11 図に結果を比較して示 す。この結果から, 機体長 10 倍位置ではブーム最小形状の ピーク圧がブーム最大形状の $3 / 4$ 程度の值となり, ブーム

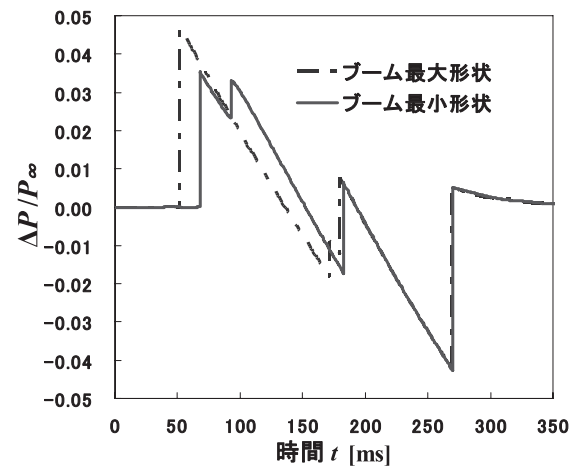

(a) 機体長 10 倍位置飛行時の圧力波形

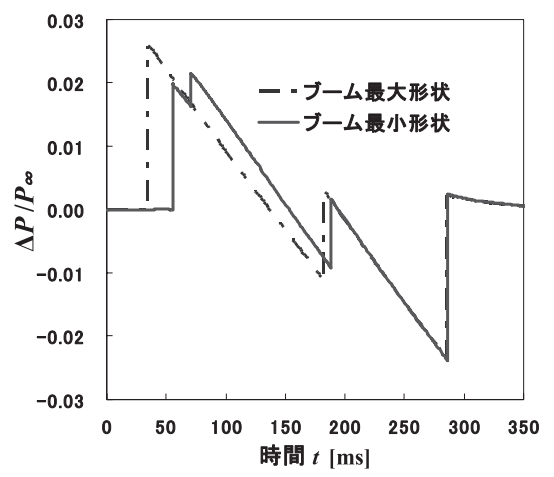

(b) 機体長 20 倍位置飛行時の圧力波形

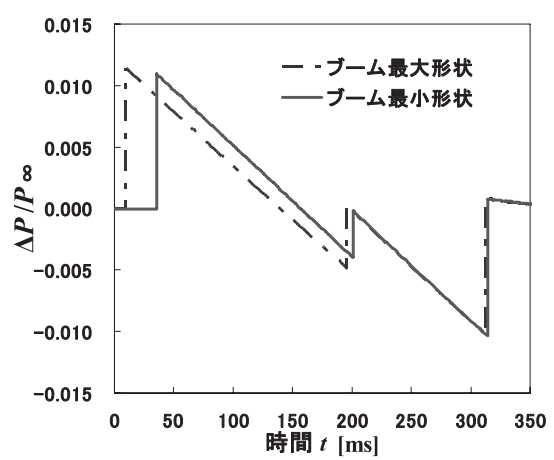

(c) 機体長 50 倍位置飛行時の圧力波形

第11図 各飛行高度での地上圧力波形の比較 


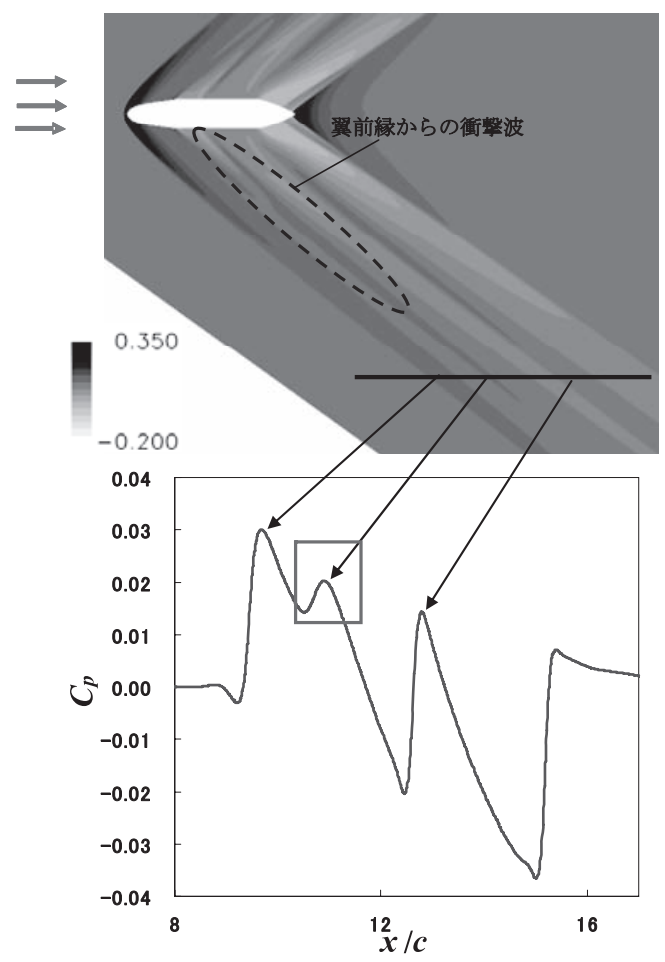

第 12 図 ブーム最小形状の $y=0$ 断面（対称面）での $C_{p}$ 分布およ び近傍場圧力波形（2 機体長下）

の低減効果が確認できる。しかし, 伝播距離が長くなるに つれ，最小形状の先端衝撃波と直後にある 2 つの衝撃波が 統合し, 機体長 50 倍の飛行高度ではブーム最大形状と最 小形状のピーク圧は近い值をとることがわかる。すなわち, 2 つ目の衝撃波が原因となり，ブーム最小形状のブーム低 減効果が小さくなるわけである。第 12 図はブーム最小形 状の $y=0$ 断面（対称面）における機体長 2 倍直下の $C_{p}$ 分布および近傍場圧力波形を示す。第 12 図より, 先述した 2 つ目の衝撃波は翼前縁から発生していることが確認でき, 模型の製作上，翼の前縁に厚みをつけたことが原因である ことがわかる。

ブーム最大形状では, 胴体先端からの強い膨張波と翼前 縁からの衝撃波が干渉し, 翼前縁の衝撃波を打ち消すため 翼の厚みによる効果はほとんどない.

\section{7. 胴体が複葉翼干渉へ与える影響}

第 13 図はブーム最小形状，ブーム最大形状，および複葉 翼のみについて, $x=1.6$ 断面（翼前縁付近）の $C_{p}$ 分布 を比較して示す。この複葉翼は翼前縁および後縁に $0.2 \mathrm{~mm}$ の厚みを持たせてある。また第 14 図は，第 13 図の各々の 形状における複葉翼の下翼上面の $C_{p}$ 分布を示す. 加えて第 1 表には各々の形状の抵抗係数を示す. 第 13 図から, ブー ム最小形状では, 図中の四角枠で示した領域から発生した 圧縮波が複葉翼にあたっており，またブーム最大形状では 図中の四角枠で示した領域から発生した膨張波が複葉翼に あたっていることが確認できる。そのため第 14 図に示す ように, 複葉翼のみの場合に比べて, 衝撃波と膨張波の理 想的な干渉が達成されている領域が小さい。また第 14 図

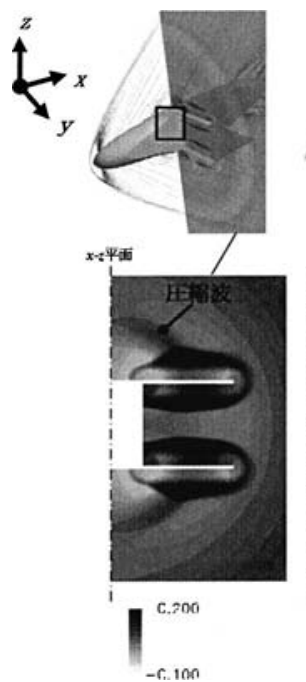

(a)

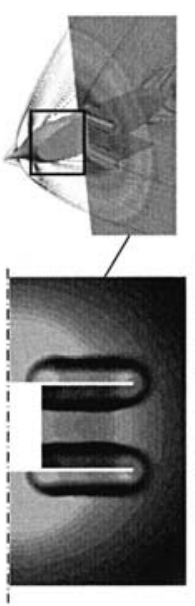

(b)

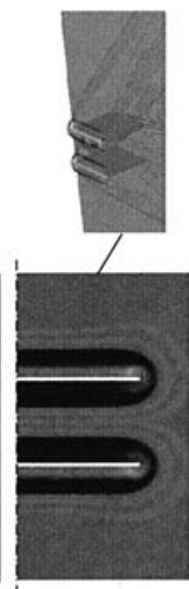

(c)
第 13 図 $x=1.6$ 断面（翼前縁付近）の $C_{p}$ 分布の比較

(a) ブーム最小形状，(b) ブーム最大形状，(c) 複葉翼のみ.

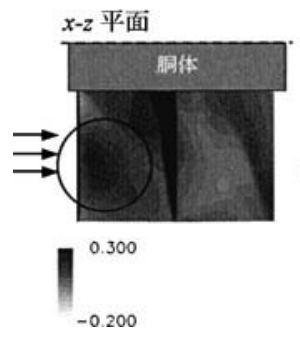

(a)

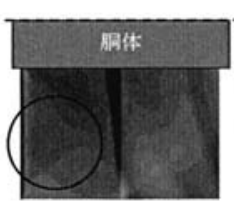

(b)

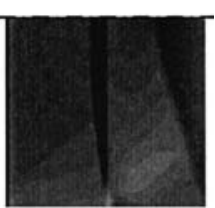

(c)
第 14 図 下翼上面の $C_{p}$ 分布の比較

(a) ブーム最小形状, (b) ブーム最大形状, (c) 複葉翼のみ.

第 1 表 抵抗係数の比較

\begin{tabular}{lccc}
\hline & 全機 & 胴体 & 翼 \\
\hline ブーム最小形状 & 0.1740 & 0.1167 & 0.0573 \\
ブーム最大形状 & 0.2414 & 0.1891 & 0.0522 \\
複葉翼のみ & - & - & 0.0550 \\
\hline
\end{tabular}

の (a) と (b) を比較すると, 胴体先端形状が異なることで, 胴体から発生して複葉翼にあたる衝撃波および膨張波が変 化し, 丸印で示す圧力分布に違いが見られる. 同じ複葉翼 を用いた場合でも，複葉翼の衝撃波干渉の様子が大きく変 化することが確認できる。 また第 1 表の抵抗值の比較結果 から, 翼部分の抵抗值は胴体部分の抵抗值に比べ各形状で 差が小さく, 全機の抵抗值は胴体部分の影響が大きいこと がわかる。

\section{8. バリスティックレンジを用いた超音速自由飛行実験}

8.1 実験設備 名古屋大学電離気体力学研究室に設置 されているバリスティックレンジを用いて実験を行った．本 実験に用いたバリスティックレンジの概念図を第 15 図に示 す、バリスティックレンジは, 本来その名の通り弾道の飛行 試験を行う装置であるため, 加速管断面が円形であること が多い. 従って, 本実験模型のような非軸対象物体の飛行 試験を行う際には，実験摸型のロール制御が難しいという 


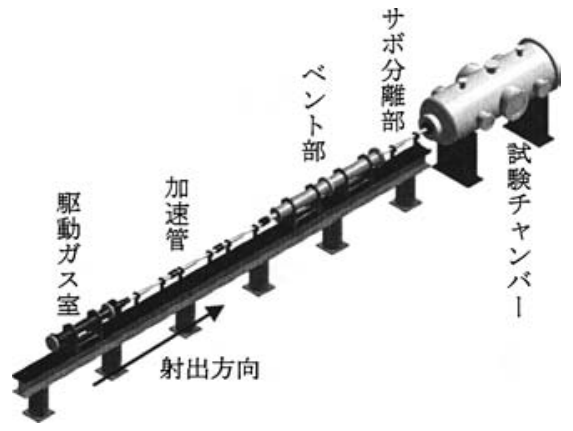

第 15 図 バリスティックレンジ概念図

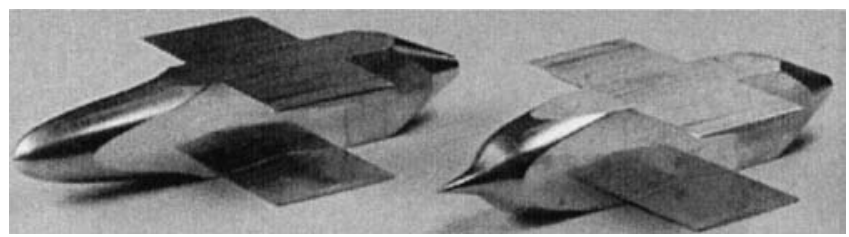

(a) ブーム最小形状

(b) ブーム最大形状

第 16 図 製作した翼胴型実験模型

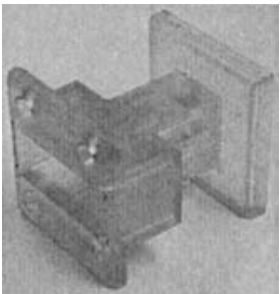

(a) 加速用サボ

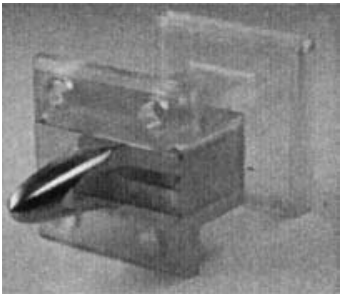

(b) 加速用サボを装着した模型
第 17 図 加速用サボと実験模型

問題が挙げられる。そこで，本実験で使用したバリスティッ クレンジは複雑形状の飛行に対応するため断面形状を正方 形とし，実験模型のロール方向への回転を抑えている. 従っ て，超音速複葉翼のような非軸対称物体のフリーフライト 実験に適している。本実験では第 15 図の駆動ガス室に圧 縮ヘリウムを $1.7 \mathrm{MPa}$ まで充填し, 試験チャンバー内の圧 力を $50 \mathrm{kPa}$ まで減圧させることで, 実験模型をマッハ数 約 1.7 で飛行させた。また試験チャンバー内に圧力センサ （PCB Piezotronics，H112A21）を設置し，模型の飛行経 路から直下方向 $150 \mathrm{~mm}$ 位置で圧力波形を計測した。さら にシャドウグラフ法を用いて模型まわりの流れの可視化も 行った．本可視化には高速度カメラ（Shimadzu, HPV-1) を用い，1 フレーム時間は $16 \mu \mathrm{s}, 1$ フレームの露光時間は $2 \mu \mathrm{s}$ とした.

8.2 翼胴型実験模型 第 16 図に製作した模型形状を示 す．実験模型の材質はA7075（超ジュラルミン）である. 本 模型は製作コストを抑えるために，ブーム最小形状とブー 厶最大形状の両模型とも，第 8 図で示した実験模型形状に 対して後方形状を円錐とした。 また, 第 17 図 (a) は加速用 サボを示し，(b) は加速用サボを装着した模型を示す。こ のサボは模型を内側へおさめ, 加速管内に設置し, 高圧夕

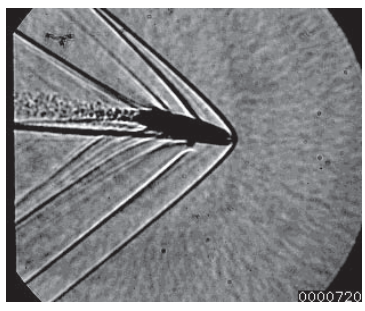

(a)

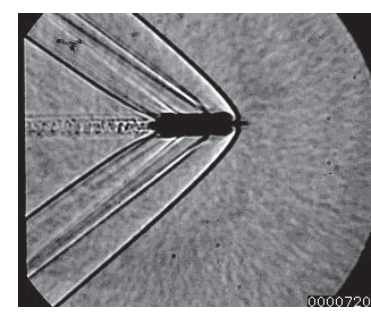

(b)
第 18 図 シャドウグラフによる可視化結果

(a) ブーム最小形状：迎え角約 $-15^{\circ}$, マッ八数約 1.71

(b) ブーム最大形状：迎え角 $0^{\circ}$, マッ八数約 1.70 .

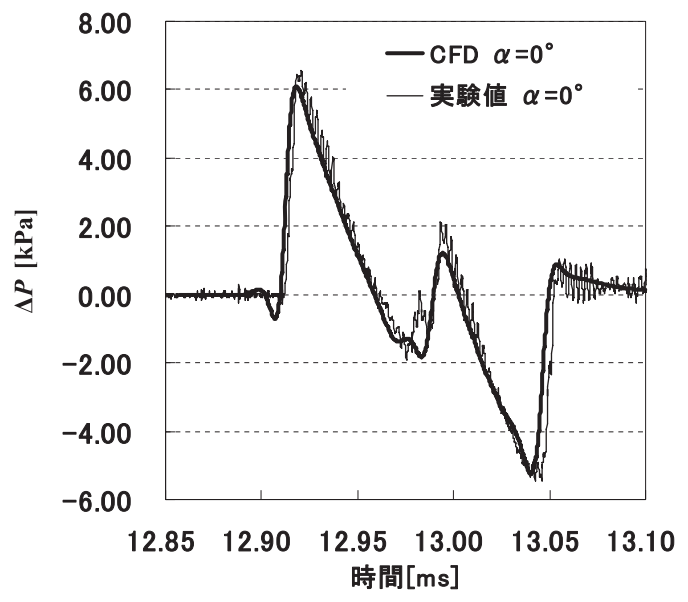

第 19 図 実測圧力波形と CFD 解析結果の比較

ンクからの駆動ガス圧力によって模型を加速させるために 用いている。サボ後方部はブリッジマンシールとなってお り，加速管をシールし後方の高圧駆動ガスを逃がすことな く圧力を受け，模型を加速させることができる．また模型 と共に加速されたサボは, 試験部直前のサボ分離部管内で 模型との抵抗差によって自然分離する ${ }^{11)}$.

8.3 実験結果 ブーム最小形状およびブーム最大形状 各々5 回の自由飛行実験を実施した。ここでは飛行実験の 中で最も水平に近い状態で飛行した結果について議論する. 第 18 図 (a) はブーム最小形状（迎え角約 $-15^{\circ}$, マッハ数 約 1.71)，(b) はブーム最大形状（迎え角 $0^{\circ}$, マッ八数約 1.70）のシャドウグラフの可視化結果を示す。第 18 図より, ブーム最大形状は水平に飛行しているが, ブーム最小形状 は，マイナスの迎え角がついていることが確認できる。こ の理由としては，サボとのはめあい具合および模型の姿勢 安定性によるものだと考えられる。サボと模型のはめあい が緩ければ，加速管に装着した時点で，模型に若干の負の 迎え角がつき, 加えて模型の姿勢安定性により, 自由飛行 時にさらに大きな迎え角がつくと考えられる，今後，実験 を通じたさらなる考察と改善策が必要である.

最後に，CFD 解析結果の妥当性を検討するため，第 19 図に迎え角 $0^{\circ}$ で飛行したブーム最大形状の実測圧力波形と $\mathrm{CFD}$ 解析結果を比較して示す。なお, CFD 解析ではマッ 八数 1.7 , 迎え角 $0^{\circ}$ に設定し, 実験結果と同じ条件にした。 
ここで示した実測波形は, 圧力值から衝撃波到達前の圧力 值の平均を差し引き, 圧力值のゼロ点補正を行っている。 イズ除去などフィルター処理は施していない. また, CFD 解析から得られた圧力波形は, 圧力センサでの反射を考慮 し, 圧力值を 2 倍して示している. 第 18 図 (b) と第 19 図 の結果を比較すると, 先端の圧力ピークは胴体先端から発 生した衝撃波に起因し, 後端の負の圧力ピークは胴体後端 から発生した膨張波に起因することがわかる。また波形中 央部の圧力ピークは, 翼間での衝撃波干渉で相殺しきれず に翼間からもれた衝撃波に起因する圧力ピークであり，実 験と CFD 解析の両結果から確認できる。実測波形と CFD 解析で得られた波形を比較すると, 先端ピーク圧および後 端ピーク圧はよく一致し, 圧力波形もよい一致を示してい る. 以上より, 波形パラメータ法の入力として用いた近傍 場圧力波形の CFD 解析結果の信頼性を確認でき, 予測さ れるブーム強度の妥当性を確認できた。

\section{9. 結論}

本研究では胴体先端形状修正による翼胴型超音速複葉翼 機のソニックブーム低減化を検討した。胴体先端形状の設 計では複葉翼の影響を無視し, ランダムサーチ法と先端衝 撃波強度の簡易推算式を用いてブーム最小形状とブーム最 大形状を求めた。 得られた 2 つの形状について CFD 解析 を行い, 地上ブーム波形を推算した。 その結果ブーム最小 形状はブーム最大形状に比べて, 先端ピーク圧を約 $15 \%$ 低 減可能であることがわかった。一方, 翼の前縁および後縁 に厚みを持たせた製作模型では，近傍場ではピーク圧の低 減がみられたが，遠方場ではブーム低減効果が小さいこと がわかった。 その原因は, 翼前縁から発生する衝撃波が胴 体から発生した衝撃波と統合するためであることを確認し た。さらに，胴体から発生する衝撃波が複葉翼の衝撃波干 渉に与える影響を考察した結果, 胴体から発生する圧縮波 および膨張波が複葉翼にあたり, 複葉翼のみの場合に比べ て理想的な衝撃波の干渉が達成されている領域が小さくな ることがわかった。 また, 胴体先端形状が変化した結果, 胴 体から発生して複葉翼にあたる衝撃波および膨張波が変化 し, 複葉翼の衝撃波干渉の様子が変化することがわかった。 最後に, バリステイックレンジを用いた超音速自由飛行実 験を行った結果, 実測波形と CFD 解析で得られた圧力波 形はよく一致し，CFD 解析結果および予測されるブーム強 度の信頼性を確認した。

\section{参 考 文 献}

1) Kusunose, K.: A New Concept in the Development of Boomless Supersonic Transport, First International Conference on Flow Dynamics, Sendai, Japan, November 2004.

2) Kusunose, K., Matsushima, K., Goto, Y., Yamashita, H., Yonezawa, M., Maruyama, D. and Nakano, T.: A Fundamental Study for the Development of Boomless Supersonic
Transport Aircraft, AIAA Paper 2006-0654, January 2006.

3) Yonezawa, M. and Obayashi, S.: Reducing Drag Penalty in the Three-Dimensional Supersonic Biplane, Proc. IMechE, Part G: J. Aerospace Engineering, 223, G7 (2009), pp. 889891.

4) Yamashita, H., Obayashi, S. and Kusunose, K.: Reduction of Drag Penalty by Means of Plain Flaps in the Boomless Busemann Biplane, Int. J. Emerging Multidisciplinary Fluid Sci., 1 (2009), pp. 141-164.

5) Kusunose, K., Matsushima, K., Obayashi, S., Furukawa, T., Kuratani, N., Goto, Y., Maruyama, D., Yamashita, H. and Yonezawa, M.: Aerodynamic Design of Supersonic Biplane: Cutting Edge and Related Topics, The 21st Century COE Program International COE of Flow Dynamics Lecture Series, Vol. 5, Tohoku University Press, Sendai, 2007, pp. 7583.

6) Kuratani, N., Nagai, H., Asai, K., Ogawa, T. and Obayashi, S.: Visualization of Interacting Flow Field between Busemann's Biplane in Supersonic Flow, 13th International Symposium on Flow Visualization, ISFV13(301), Nice, France, July 2008.

7）小高雄介, 楠瀬一洋 : 超音速複葉翼形状及び翼胴形状の空力特性 に関する基礎研究，日本航空宇宙学会論文集， 57 (2009), pp. 217-224.

8) Pawlowski, J. W., Graham, D. H., Boccadoro, C. H., Coen, P. G. and Maglein, D. J.: Origins and Overview of the Shaped Sonic Boom Demonstration Program, AIAA Paper 2005-5, 2005.

9) Plotkin, K. J., Haering, E. A. Jr., Murray, J. E., Maglieri, D. J., Salamone, J., Sullivan, B. M. and Schein, D.: Ground Data Collection of Shaped Sonic Boom Experiment Aircraft Pressure Signatures, AIAA 2005-0010, 43rd AIAA Aerospace Sciences Meeting and Exhibit, Reno, 2005.

10) Northrop-Grumman Corporation's Modified U.S. Navy F-5E Shaped Sonic Boom Demonstration (SSBD) Aircraft, NASA, http://www.dfrc.nasa.gov/Gallery/Photo/SSBD/HTML/ EC03-0210-1.html, 2004 (cited 15 March 2010).

11) Sasoh, A. and Oshiba, S.: Impactless, In-Tube Sabot Separation Technique Useful for Modest-Sized Supersonic Ballistic Ranges, Rev. Sci. Instrum., 77 (2006), No. 105106.

12) 豊田 篤, 大久保正幸, 大林 茂, 清水克也, 佐宗章弘：バリス ティックレンジを用いた超音速複葉翼低ブーム特性の検証実験, 第 41 回流体力学講演会, 東京, 2009, pp. 151-154.

13) Toyoda, A., Okubo, M., Obayashi, S., Shimizu, K., Matsuda, A. and Sasoh, A.: Ballistic Range Experiment on the Low Sonic Boom Characteristics of Supersonic Biplane, AIAA 2010-0873, 48th AIAA Aerospace Sciences Meeting and Exhibit, Orlando, 2010.

14) Carlson, H. W. and Maglieri, D. J.: Review of Sonic Boom Generation Theory and Prediction Methods, J. Acoust. Soc. Am., 51 (1972), pp. 675-685.

15) Thomas, C. L.: Extrapolation of Sonic Boom Pressure Signatures by the Wave Parameter Method, NASA TN D-6832, June 1972.

16) Nakahashi, K., Ito, Y. and Togashi, F.: Some Challenge of Realistic Flow Simulations by Unstructured Grid CFD, Int. J. Numer. Meth. Fluids, 43 (2003), pp. 769-783.

17) Ito, Y. and Nakahashi, K.: Surface Trianglation for Polygonal Models Based on CAD Data, Int. J. Numer. Meth. Fluids, 39 (2002), pp. 75-99.

18) Sharov, D. and Nakahashi, K.: A Boundary Recovery Algorithm for Delaunay Tetrahedral Meshing, Proceedings of the 5th International Conference on Numerical Grid Generation in Computational Field Simulations, 1996, pp. 229-238. 